\title{
EFFECT OF PLANT RESIDUALS, ORGANIC FERTILIZER AND SOME TREATMENTS THAT REDUCE SALINITY EFFECT ON GROWTH, YIELD AND QUALITY OF EGGPLANT (Solanum melongea L.) \\ El-Sayed, Hala A.* ; Aida M. Abd El-Rahim ${ }^{* *}$; E. I. El-Gamily* and E. E. M. Ismail ${ }^{\star \star}$ \\ "Vegetables and Floriculture Dept., Fac. Agric., Mansoura University. \\ ${ }^{* *}$ Horticulture Research Institute, Agricultural Research Center, Giza.
}

\begin{abstract}
Two field experiments were carried out at a Farm in El-Mataryia district, Dakahlia Governorate during the two growing seasons of 2011 and 2012 to study the effect of organic fertilization and ammonium thiosulfate (ATS) levels that reduce salinity effect on vegetative growth, yield and its components and chemical constituents of eggplant crop Black Beauty cultivar. The experiments were carried out by using split - plots system in a randomized complete blocks design with three replications. The main plots were arranged with organic fertilization treatments. The sub plots were assigned to ammonium thiosulfate levels.

The obvious results of this investigation can be summarized as follows:

Using farmyard manure (FYM) and potassium humate $(\mathrm{KH})$ treatments significantly increased all studied characters as compared with other organic fertilization treatments in both seasons. Application rice residues (RS) caused significant increases on all studied characters as compared with control treatment (without organic fertilization) in both seasons.

All studied characters were significantly influenced by different ATS levels in the both seasons. The highest values of these traits were resulted from using $30 \mathrm{~L} / \mathrm{fed}$ and $40 \mathrm{~L} /$ fed of ATS, respectively in both seasons.

Generally, it could be recommended that using FYM or $\mathrm{KH}$, respectively along with $30 \mathrm{~L}$ ATS/fed to enhance vegetative growth characters, yield and its components and chemical constituents of eggplant fruits. Also, it could be recommended that using $\mathrm{RS}$ combined with $30 \mathrm{~L}$ ATS/fed to enhance studied characters as compared with control treatment (without organic fertilization) and also to reduce sources of environmental pollution and maintain human health.
\end{abstract}

\section{INTRODUCTION}

Eggplant (Solanum melongea L.) is one of the oldest and popular vegetable crops in Egypt. It is cultivated for local consumption as well as for exportation. It is grown in most cultivated area in Egypt.

It is well known that high productivity of any crop is the final goal of many factors and operations. In addition, the pronounced role of the agronomical processes such as utilization of organic fertilizers (rice residues, farmyard manure and potassium humate) and ammonium thiosulfate levels are consider as important factors to reduce salinity effect on growth and yield of eggplant crop. 
In general, soil optimum acidity $(\mathrm{pH})$ for most vegetables cultivation is between 6.0 to 6.5. Eggplant is considered as a moderately sensitive crop to salinity (Bruria et al., 1986).

Rice residues improved the physic - chemical and microbiological properties of saline soil. (Dileep et al. 2006).

Rice residues are important natural resource and recycling of these residues improves soil physical, chemical and biological properties (Mandal et al., 2004 and Brar and Walia, 2010).

Soil $\mathrm{pH}$ is greatly influenced by addition of organic matter (OM) through different organic amendments (Walker et al., 2004). Organic manures may increase soil fertility and thus the crop production potential possibly by changes in the soils physical and chemical properties including nutrient bioavailability, soil structure, water holding capacity, cation exchange capacity, reduce soil $\mathrm{pH}$, microbial community and activity (Muhammad and Khattak, 2009). Bryan and Jeff (2003) revealed that the organic materials contain carbon, which serves as a food resource for soil organisms such as bacteria, algae, fungi and earthworms. They also found that increasing levels of soil humus has a number of benefits for plants which increased water and nutrient holding capacity, reserve of slow release nutrients, resistance to soil $\mathrm{pH}$ change and soil warmth. Furthermore, humic acid increased stimulation of plant growth due to hormones. Humic acid is particularly used to decrease the negative effects of chemical fertilizers and could have beneficial effect on nutrition of plants (Martinez et al., 1983).

Ammonium thiosulfate is a standard product of the USA fluid fertilizer. Sales of ATS have steadily increased owing to its natural advantages; a) Compatibility with most fluid NPK sources. b) More rapid oxidation than elemental sources. c) Higher analysis than other fluid sulfur (S) sources. d) ATS can enhance micronutrient availability, alkaline soil, saline soil, slow soil urease, slow nitrification and improve the availability of phosphorus fertilizers (Goos, 1995).

Therefore, the aim of this investigation was to determine the effect of organic fertilizers (rice residues, farmyard manure and potassium humate) and ammonium thiosulfate (ATS) that reduce salinity effect on vegetative growth, yield and its components and chemical constituents of eggplant fruits. Also, the aim of this investigation was to reduce air pollution resulted from rice straw burning for maintain human health and reduce sources of environmental pollution.

\section{MATERIALS AND METHODS}

The present study was carried out during 2011 and 2012 seasons at a private Farm in El-Mataryia district, Dakahlia Governorate. The goal of these trials was to clarify the effect of organic fertilization and ammonium thiosulfate (ATS) levels on vegetative growth, yield and its components and chemical constituents of eggplant crop, Black Beauty cultivar. 
The experimental layout was a split - plots system in a randomized complete blocks design with three replications. The main plots were arranged with four organic fertilization treatments as follows;

1- Without organic fertilization (control treatment).

2- Rice residues (RS) at the rate of $4 \mathrm{t} / \mathrm{fed}$.

3- Farmyard manure (FYM) at the rate of $15 \mathrm{~m}^{3} / \mathrm{fed}$.

4- Potassium humate $(\mathrm{KH}) 4.5 \%$ at the rate $2 \mathrm{~L} / \mathrm{fed}$.

Rice residues (RS) and farmyard manure (FYM) were added to the experimental units before transplanting in the interior of ridges and then turned over via hack. Before that, samples of RS and FYM were taken to estimate its chemical analysis as shown in Table 1.

Table 1: Chemical analysis of RS and FYM during the two seasons.

\begin{tabular}{|l|c|c|c|c|}
\hline \multirow{2}{*}{ Contents } & \multicolumn{2}{c|}{$\begin{array}{c}\text { Rice residues } \\
\text { (RS) }\end{array}$} & \multicolumn{2}{c|}{$\begin{array}{c}\text { Farmyard manure } \\
\text { (FYM) }\end{array}$} \\
\cline { 2 - 5 } & $\mathbf{2 0 1 1}$ & $\mathbf{2 0 1 2}$ & $\mathbf{2 0 1 1}$ & $\mathbf{2 0 1 2}$ \\
\hline Organic matter (OM) \% & 44.30 & 42.60 & 35.20 & 36.10 \\
\hline $\mathrm{C} \%$ & 25.80 & 26.9 & 20.20 & 21.10 \\
\hline $\mathrm{N} \%$ & 1.09 & 1.07 & 1.32 & 1.41 \\
\hline $\mathrm{C} / \mathrm{N}$ & $23: 7$ & $23: 2$ & $15: 5$ & $14: 8$ \\
\hline $\mathrm{P} \%$ & 0.19 & 0.18 & 0.26 & 0.29 \\
\hline $\mathrm{K} \%$ & 0.14 & 0.13 & 0.16 & 0.15 \\
\hline $\mathrm{pH}(1: 5)$ & 4.90 & 4.80 & 6.10 & 6.20 \\
\hline $\mathrm{EC}(1: 10)$ & 5.10 & 5.20 & 4.20 & 4.10 \\
\hline
\end{tabular}

The sub plots were assigned to ammonium thiosulfate (ATS $12-0$ $0-26$ S) levels i.e. 0, 10, 20, 30 and $50 \mathrm{~L} / \mathrm{fed}$. Potassium humate (KH) $4.5 \%$ and ammonium thiosulfate (ATS) were applied separately as follows; $25 \%$ before transplanting, $25 \%$ at 4 weeks after transplanting, $25 \%$ at 8 weeks after transplanting and $25 \%$ at 12 weeks after transplanting. The common recommended chemical fertilizers $(\mathrm{N}, \mathrm{P}$ and $\mathrm{K})$ rates (mineral) were carried out at the rate of $150 \mathrm{~kg}$ ammonium sulfate $(20.5 \% \mathrm{~N}), 250 \mathrm{~kg}$ calcium superphosphate $\left(15.5 \% \mathrm{P}_{2} \mathrm{O}_{5}\right)$ and $50 \mathrm{~kg}$ potassium sulfate $\left(48.52 \% \mathrm{~K}_{2} \mathrm{O}\right)$. All doses of chemical fertilizers were applied as following; $30 \%$ at 4 weeks after transplanting, $35 \%$ at 8 weeks after transplanting and $35 \%$ at 12 weeks after transplanting.

Each experimental unit contains 4 rows, $3.75 \mathrm{~m}$ long and $0.70 \mathrm{~m}$ width occupying an area of $10.5 \mathrm{~m}^{2}$ (i.e. $1 / 400$ feddan). The preceding winter crop was garlic (Allium sativum L.) in both seasons.

The experiments were carried out in a clay loam soil with medium fertility. Soil samples were taken at random from the experimental field area at a depth of 0 to $50 \mathrm{~cm}$ before soil preparation to measure the physical and chemical soil properties as shown in Table 2. 
El-Sayed, Hala A. et al.

Table 2: Physical and chemical soil characteristics of the experimental sites ${ }^{\star}$ during the two growing seasons.

\begin{tabular}{|c|c|c|}
\hline Soil analysis & 2011 & 2012 \\
\hline \multicolumn{3}{|c|}{ A: Mechanical analysis } \\
\hline Clay (\%) & 49.00 & 55.0 \\
\hline Silt (\%) & 30.40 & 29.4 \\
\hline Fine sand $(\%)$ & 18.70 & 12.7 \\
\hline Coarse sand (\%) & 1.90 & 2.89 \\
\hline \begin{tabular}{|l|} 
Texture class \\
\end{tabular} & Clay & Clay \\
\hline Organic matter (\%) & 1.14 & 2.91 \\
\hline \multicolumn{3}{|c|}{ B: Chemical analseis } \\
\hline $\mathrm{pH}(1: 2.5)$ & 8.12 & 8.11 \\
\hline E.C. ds $\mathrm{m}^{-1}(1: 5)$ & 1.07 & 1.90 \\
\hline Saturation percentage (SP \%) & 72.00 & 71.50 \\
\hline Available N (ppm) & 46.50 & 48.1 \\
\hline Available P (ppm) & 4.30 & 4.70 \\
\hline Exchangeable K (ppm) & 375 & 226 \\
\hline \multirow{4}{*}{$\begin{array}{l}\text { Cations } \\
\text { (meq } / 100 \mathrm{~g} \text { soil) }\end{array}$} & 1.25 & 4.25 \\
\hline & 0.67 & 2.41 \\
\hline & 3.25 & 2.93 \\
\hline & 0.31 & 0.16 \\
\hline \multirow{4}{*}{ 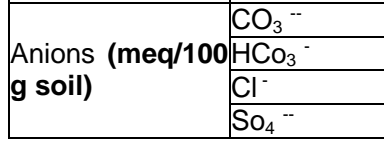 } & - & - \\
\hline & 0.94 & 4.61 \\
\hline & 2.66 & 2.73 \\
\hline & 1.88 & 2.39 \\
\hline
\end{tabular}

* Soil and Water Analysis Institute, Mansoura Lab., Agricultural Research Center (ARC).

Irrigation water was applied from El-Salam Canal. El Salam Canal water content of Nile river water and drainage water percentage (1:1). So, irrigation water was applied quality medium and saline water. So, irrigation water due to salinity of soil.

Table 3: Chemical analysis of the irrigation water of El-Salam Canal used in the experimental field ${ }^{*}$ during the two growing seasons.

\begin{tabular}{|c|c|c|c|}
\hline \multicolumn{2}{|c|}{ Properties } & 2011 & 2012 \\
\hline \multicolumn{2}{|c|}{$\mathrm{pH}$} & 8.22 & 8.12 \\
\hline \multicolumn{2}{|c|}{ E.C. $d S ~ m^{-1}$} & 1.26 & 1.25 \\
\hline \multirow{4}{*}{$\begin{array}{l}\text { Anions } \\
(\text { meq L-1) }\end{array}$} & $\mathrm{CO}_{3}{ }^{--}$ & - & - \\
\hline & $\mathrm{HCO}_{3}{ }^{-}$ & 2.30 & 2.40 \\
\hline & $\mathrm{Cl}^{-}$ & 7.61 & 7.56 \\
\hline & $\mathrm{SO}_{4}{ }^{--}$ & 2.89 & 2.87 \\
\hline \multirow{4}{*}{$\begin{array}{l}\text { Cations } \\
\left(\text { meq L }{ }^{-1}\right)\end{array}$} & $\mathrm{Ca}^{++}$ & 3.38 & 3.36 \\
\hline & $\mathrm{Mg}^{++}$ & 2.98 & 2.99 \\
\hline & $\mathrm{Na}^{+}$ & 6.30 & 6.40 \\
\hline & $\mathrm{K}^{+}$ & 0.14 & 0.15 \\
\hline \multicolumn{2}{|l|}{ SAR } & 3.53 & 3.54 \\
\hline
\end{tabular}

* Soil and Water Analysis Institute, Mansoura Lab., Agricultural Research Center (ARC).

The experimental field was well prepared through three ploughings, compaction, leveling, ridging and then divided into the experimental units with dimensions as previously mentioned. 
The transplanting was carried out during the first week of April in both seasons. The seedlings ( 45 days old) were sown on both sides of the ridges at $50 \mathrm{~cm}$ apart. The harvest was done after 90 days from transplanting at 45 days intervals in the both seasons of this study. The common agricultural practices for growing eggplant seedling according to the recommendations of Ministry of Agriculture were followed, except the factors under study.

Studied characters:

\section{A- Vegetative Growth Characters:}

At 65 days after transplanting a random sample of four guarded plants was taken from the inner rows of each sub plot to estimate plant vegetative growth characters as follows:

1- Plant height $(\mathrm{cm})$.

3- Leaves area/plant $\left(\mathrm{cm}^{2}\right)$.

2- Number of leaves/plant. leaves.

4- Fresh and dry weight of

5- Chlorophyll readings: It was measured by Minolta chlorophyll meter produced by Minolta Camera Co. LTD.

B- Yield and its Components:

The harvest was done after 90 days from transplanting at 45 days intervals (fruits were harvested all 5 days).

1 - Early yield weight in t/fed (first 3 pickings).

2- Yield weight in $\mathrm{t} / \mathrm{fed}$ (from the fourth picking till end of harvesting).

3- Total yield weight in $\mathrm{t} / \mathrm{fed}(1+2)$.

Random samples of fruits at harvesting time (from the fourth picking) were taken from each sub-plot to determine the following traits:
1- Average fruit weight $(\mathrm{g})$.
2- Average fruit diameter $(\mathrm{cm})$.

3- Average fruit height $(\mathrm{cm})$.

C- Chemical Constituents:

4- Fruit firmness $\left(\mathrm{lb} / \mathrm{m}^{2}\right)$.

Random samples of fruits at harvesting time (from the fourth picking) were taken from each sub-plot to determine the following traits:

1- Total nitrogen (\%) was determined according to the method described by Pregle (1945) using micro-Kjeldahl.

2- Total phosphorus (\%) was determined colorimetrically using the chlorostannus reduce molybdo phosphoric blue clour method in sulphoric system as described by Jackson (1967).

3- Potassium (\%) was determined using a flame photometer according to Black (1965).

4- Nitrate and nitrite contents were extracted by $2 \%$ acetic acid using of $\mathrm{N}$ 1 naphthyle ethylene diamine dihydrochlorid as an indicator. A pinkish colour intensity of the filtrate was measured by a spectrophotometer at wave length 540 n.m according to the method described by Singh (1988).

5- Total soluble solids (TSS \%) was estimated using Gali 110 refractometer as Brown and Zerban (1938).

6- Ascorbic acid (Vitamin C) was determined by titration with 2.6 dichlorophenol blue dye according to the method reported in A.O.A.C. (1990).

7- Total iron was measured in the digested plant samples using an Atomic Absorption spectrophotometer according to Chapman and Pratt (1961). 


\section{8- Dry matter and moisture \%.}

All data of this study were statistically analyzed according to the technique of variance (ANOVA) for the split-plot design as published by Gomez and Gomez (1984) using "MSTAT-C" Computer software package. Least Significant Difference (LSD) method was used to test the differences between treatment means at $5 \%$ level of probability as described by Snedecor and Cochran (1980).

\section{RESULTS AND DISCUSSION}

\section{1- Effect of organic fertilization treatments:}

As shown from data in Table 4, rice residues (RS) application caused significant increases on plant height, number of leaves/plant, plant leaf area, fresh weight of leaves, dry weight of leaves, total chlorophyll, N, P and K percentages in eggplant leaves as compared with control treatment (without organic fertilization) in both seasons of this study. Plant height, number of leaves/plant, plant leaf area, fresh weight of leaves, dry weight of leaves, total chlorophyll, N, P and $\mathrm{K}$ percentages in eggplant leaves were significantly increased by using farmyard manure (FYM) and potassium humate $(\mathrm{KH})$ treatments, respectively as compared with other organic fertilization treatments in both seasons of this study.

Application of rice residues (RS) caused significant increases on early yield weight, yield weight, total yield weight, fruit weight, diameter, height and firmness as compared with control treatment (without organic fertilization) in both seasons of this study as shown from data in Table 5. Early yield weight, yield weight, total yield weight, fruit weight, diameter, height and firmness of eggplant were significantly increased by using farmyard manure (FYM) and potassium humate $(\mathrm{KH})$ treatments, respectively as compared with other organic fertilization treatments in both seasons of this study.

As shown from data in Tables 6 and 7, using rice residues (RS) caused significant increases on $\mathrm{N}, \mathrm{P}, \mathrm{K}, \mathrm{NO}_{3}, \mathrm{NO}_{2}, \mathrm{TSS}$, vitamin $\mathrm{C}, \mathrm{Fe}$, dry matter and moisture percentages in eggplant fruits as compared with control treatment (without organic fertilization) in both growing seasons. N, P, K, $\mathrm{NO}_{3}, \mathrm{NO}_{2}$, TSS, vitamin $\mathrm{C}$, Fe, dry matter and moisture percentages in eggplant fruits were significantly increased by using farmyard manure (FYM) and potassium humate $(\mathrm{KH})$ treatments, respectively as compared with other organic fertilization treatments in both seasons of this study.

These results may be due to applying rice residues improved the physical, chemical and microbiological properties of saline soil as mentioned by Dileep et al. (2006). The obtained results are in accordance with those reported by Ali (2011).

The enhancing effects of FYM treatment may be due to the fact that organic manures are valuable source of many fertilizers and essential macro and micronutrients to plants and serves as a good natural soil texture conditioner being rich in organic matter (Mishref et al., 2000). The obtained results are in accordance with those documented by Suge et al. (2011). 
J. Plant Production, Mansoura Univ., Vol. 4 (6), June, 2013 $4-5$ 
El-Sayed, Hala A. et al.

6-7 
The enhancing effect of $\mathrm{KH}$ treatment may be due to potassium humate which increased stimulation of plant growth due to hormones and could have beneficial effect on nutrition of plants (Martinez et al., 1983). The obtained results are in accordance with those of Selim et al. (2009) and Azarpour et al. (2012).

\section{2- Effect of ammonium thiosulfate (ATS) levels:}

Plant height, number of leaves/plant, plant leaf area, fresh weight of leaves, dry weight of leaves, total chlorophyll, N, P and K percentages in eggplant leaves were significantly influenced by different ATS levels in the two growing seasons of this study as shown from data in Table 4. The highest values of these traits were resulted from using $30 \mathrm{~L} / \mathrm{fed}, 40 \mathrm{~L} / \mathrm{fed}, 20$ $\mathrm{L} / \mathrm{fed}$ and $10 \mathrm{~L} / \mathrm{fed}$ of ATS, respectively in both seasons of this study.

Early yield weight, yield weight, total yield weight, fruit weight, diameter, height and firmness of eggplant were significantly influenced by different ATS levels in the two growing seasons as shown from data in Table 5. The highest values of these traits were resulted from using $30 \mathrm{~L} / \mathrm{fed}$ and 40 L/fed of ATS, respectively in both seasons of this study.

$\mathrm{N}, \mathrm{P}, \mathrm{K}, \mathrm{NO}_{3}, \mathrm{NO}_{2}, \mathrm{TSS}$, vitamin $\mathrm{C}, \mathrm{Fe}$, dry matter and moisture percentages in eggplant fruits were significantly influenced by different ATS levels in the two growing seasons of this study as shown from data in Tables 6 and 7. The highest values of these traits were resulted from using $30 \mathrm{~L} / \mathrm{fed}$ and $40 \mathrm{~L} / \mathrm{fed}$ of ATS, respectively in both experiments.

The results may be due to ATS can enhanced micronutrients availability of saline soil and improved the availability of phosphorus fertilizers (Goos,1995) as well as enhanced micronutrients availability and soil $\mathrm{pH}$ change due to it was content of $\mathrm{S}$ and $\mathrm{SO}_{4}$. Similar results were reported by Wilson et al. (2011), Zadravec (2011) and Seehuber et al. (2012).

\section{3- Effect of the interaction between organic fertilization treatments and ammonium thiosulfate levels:}

The interaction between organic fertilization treatments and ammonium thiosulfate levels had a significant effect on most studied characters as shown from data in Tables 4, 5, 6 and 7. We have enough reported the significant interaction between organic fertilization treatments and ammonium thiosulfate levels on early yield weight, yield weight, total yield weight of eggplant. The favourable interaction treatments of organic fertilization treatments and ammonium thiosulfate levels on yields was using FYM and $\mathrm{KH}$, respectively with $30 \mathrm{~L} / \mathrm{fed}$ of ATS in both seasons of this study (Tables 8, 9 and 10). These results may be due to the role of organic manure which enhanced physico - chemical and biological characteristics of soils also the role of ATS which it was enhanced micronutrient availability of saline soil and improved $\mathrm{pH}$ of soil. 
El-Sayed, Hala A. et al.

Table 8: Early yield weight (first 3 pickings) of eggplant as affected by the interaction between organic fertilization and ammonium thiosulfate levels during 2011 and 2012 seasons.

\begin{tabular}{|c|c|c|c|c|c|}
\hline \multirow{2}{*}{ Organic fertilization } & \multicolumn{5}{|c|}{ ATS levels } \\
\hline & $0 \mathrm{~L} / \mathrm{fed}$ & $10 \mathrm{~L} / \mathrm{fed}$ & $20 \mathrm{~L} / \mathrm{fed}$ & $30 \mathrm{~L} / \mathrm{fed}$ & $40 \mathrm{~L} / \mathrm{fed}$ \\
\hline \multicolumn{6}{|c|}{2011 season } \\
\hline Without (control) & 1.643 & 1.748 & 1.860 & 2.040 & 2.081 \\
\hline RS $\quad(4 \mathrm{t} /$ fed $)$ & 2.107 & 2.171 & 2.314 & 2.544 & 2.418 \\
\hline FYM $\left(15 \mathrm{~m}^{3} / \mathrm{fed}\right)$ & 2.637 & 2.763 & 2.870 & 3.138 & 3.064 \\
\hline $\mathrm{KH} \quad(2 \mathrm{~L} / \mathrm{fed})$ & 2.341 & 2.451 & 2.543 & 2.719 & 2.657 \\
\hline F. test & \multicolumn{5}{|c|}{${ }^{*}$} \\
\hline LSD (5\%) & \multicolumn{5}{|c|}{0.152} \\
\hline \multicolumn{6}{|c|}{2012 season } \\
\hline Without (control) & 1.61 & 1.70 & 1.81 & 2.09 & 2.53 \\
\hline RS $\quad(4 \mathrm{t} /$ fed $)$ & 2.04 & 2.15 & 2.25 & 2.43 & 2.38 \\
\hline FYM $\left(15 \mathrm{~m}^{3} / \mathrm{fed}\right)$ & 2.68 & 2.80 & 2.84 & 3.09 & 3.01 \\
\hline $\mathrm{KH} \quad(2 \mathrm{~L} / \mathrm{fed})$ & 2.25 & 2.51 & 2.55 & 2.73 & 2.59 \\
\hline F. test & \multicolumn{5}{|c|}{${ }^{*}$} \\
\hline $\operatorname{LSD}(5 \%)$ & \multicolumn{5}{|c|}{0.163} \\
\hline
\end{tabular}

RS = Rice residues $\quad F Y M=$ farmyard manure $\quad \mathrm{KH}=$ Potassium humate

ATS = Ammonium thiosulfate (12-0-0-26 NPKS)

Table 9: Yield weight (from the fourth picking till end of harvesting) of eggplant as affected by the interaction between organic fertilization and ammonium thiosulfate levels during 2011 and 2012 seasons.

\begin{tabular}{|c|c|c|c|c|c|}
\hline \multirow{2}{*}{ Organic fertilization } & \multicolumn{5}{|c|}{ ATS levels } \\
\hline & $0 \mathrm{~L} / \mathrm{fed}$ & $10 \mathrm{~L} /$ fed & $20 \mathrm{~L} / \mathrm{fed}$ & $30 \mathrm{~L} / \mathrm{fed}$ & $40 \mathrm{~L} / \mathrm{fed}$ \\
\hline \multicolumn{6}{|c|}{2011 season } \\
\hline Without (control) & 3.546 & 3.762 & 3.968 & 4.376 & 4.157 \\
\hline RS $\quad$ (4 t/fed $)$ & 4.210 & 3.638 & 4.925 & 5.354 & 5.132 \\
\hline FYM $\left(15 \mathrm{~m}^{3} / \mathrm{fed}\right)$ & 5.569 & 5.821 & 6.035 & 6.247 & 6.157 \\
\hline KH $\quad(2 \mathrm{~L} /$ fed $)$ & 4.978 & 5.199 & 5.383 & 5.733 & 5.610 \\
\hline F. test & \multicolumn{5}{|c|}{ * } \\
\hline LSD (5 \%) & \multicolumn{5}{|c|}{0.145} \\
\hline \multicolumn{6}{|c|}{2012 season } \\
\hline Without (control) & 3.534 & 3.708 & 3.930 & 4.189 & 4.256 \\
\hline RS $\quad(4 \mathrm{t} /$ fed $)$ & 4.346 & 4.599 & 4.797 & 5.170 & 5.033 \\
\hline FYM $\left(15 \mathrm{~m}^{3} / \mathrm{fed}\right)$ & 5.635 & 5.903 & 5.983 & 6.191 & 6.024 \\
\hline $\mathrm{KH} \quad(2 \mathrm{~L} / \mathrm{fed})$ & 4.803 & 5.023 & 5.406 & 5.769 & 5.648 \\
\hline F. test & \multicolumn{5}{|c|}{${ }^{*}$} \\
\hline LSD (5\%) & \multicolumn{5}{|c|}{0.100} \\
\hline
\end{tabular}

RS = Rice residues $\quad F Y M=$ farmyard manure

ATS = Ammonium thiosulfate (12-0-0-26 NPKS) 
Table 10: Total yield of early yield and yield weight of eggplant as affected by the interaction between organic fertilization and ammonium thiosulfate levels during 2011 and 2012 seasons.

\begin{tabular}{|c|c|c|c|c|c|}
\hline \multirow{2}{*}{ Organic fertilization } & \multicolumn{5}{|c|}{ ATS levels } \\
\hline & $0 \mathrm{~L} / \mathrm{fed}$ & $10 \mathrm{~L} / \mathrm{fed}$ & $20 \mathrm{~L} / \mathrm{fed}$ & $30 \mathrm{~L} / \mathrm{fed}$ & $40 \mathrm{~L} / \mathrm{fed}$ \\
\hline \multicolumn{6}{|c|}{2011 season } \\
\hline Without (control) & 5.189 & 5.510 & 5.828 & 6.416 & 6.238 \\
\hline RS $\quad(4 \mathrm{t} / \mathrm{fed})$ & 6.317 & 5.809 & 7.239 & 7.898 & 7.550 \\
\hline FYM $\left(15 \mathrm{~m}^{3} / \mathrm{fed}\right)$ & 8.206 & 8.584 & 8.905 & 9.385 & 9.221 \\
\hline $\mathrm{KH} \quad(2 \mathrm{~L} / \mathrm{fed})$ & 7.319 & 7.650 & 7.926 & 8.452 & 8.267 \\
\hline F. test & \multicolumn{5}{|c|}{ * } \\
\hline $\operatorname{LSD}(5 \%)$ & \multicolumn{5}{|c|}{0.160} \\
\hline \multicolumn{6}{|c|}{2012 season } \\
\hline Without (control) & 5.153 & 5.415 & 5.747 & 6.286 & 6.793 \\
\hline $\begin{array}{ll}\mathrm{RS} & (4 \mathrm{t} / \mathrm{fed}) \\
\end{array}$ & 6.388 & 6.750 & 7.047 & 7.607 & 7.416 \\
\hline FYM $\left(15 \mathrm{~m}^{3} / \mathrm{fed}\right)$ & 8.319 & 8.706 & 8.827 & 9.289 & 9.038 \\
\hline KH $\quad(2 \mathrm{~L} / \mathrm{fed})$ & 7.056 & 7.537 & 7.963 & 8.506 & 8.245 \\
\hline F. test & \multirow{2}{*}{\multicolumn{5}{|c|}{0.175}} \\
\hline LSD (5\%) & & & & & \\
\hline
\end{tabular}

RS = Rice residues $\quad F Y M=$ farmyard manure $\quad \mathrm{KH}=$ Potassium humate

ATS = Ammonium thiosulfate (12 - 0-0-26 NPKS)

\section{REFERENCES}

A.O.A.C. (1990). Official Methods of Analysis. $15^{\text {th }}$ Ed. Association of Official Analytical Chemists, Inc., Virginia, USA, pp: 770-771.

Ali, L.K.M. (2011). A study of some methods of waste management of rice through its impact on soil physical properties, N, P and K contents in maize yield and water use efficiency under different tillage systems. Australian J. of Basic and Applied Sci., 5 (5): 1017-1034.

Azarpour, E. ; M.K. Motamed ; M. Moraditochaee and H.R. Bozorgi (2012). Effects of bio, mineral nitrogen fertilizer management under humic and foliar spraying on fruit yield and several traits of eggplant (Solanum melongene L.). African J. of Agric. Res., 7 (7): 1104-1109.

Black, C.A. (1965). Methods of soil analysis. Part I- Physical and mineralogical properties. A.S.A. Madison, Wisc., USA.

Brar, A.S. and U.S. Walia (2010). Rice residue and load in conjunction with weed control treatments - interference with growth and development of Phalaris minor Retz and wheat (Triticum aestivum L.). Indian J. of Weed Sci., 42 (3/4): 163-167.

Brown, C.A. and F.W. Zerban (1938). Physical and chemical methods of sugar analysis. John Wiley and Sons, Inc. London, pp. 1353.

Bruria, H. ; A. Meoro and J. Shalevet (1986). Salt tolerance of eggplant. Plant and Soil, 95: 9-13.

Bryan, H. and S. Jeff (2003). Humic acid effect on potato response to phosphorus. Idaho Potato Conf., Jan., 22-23, 2003, 29 (3): 1407-1422.

Chapman, H.D. ; F. Paker and P. Pratt (1961). Methods of soil analysis. Part II, A.S.A. Madison, Wisc., USA. 
Dileep, K. ; A.K. Dixit and A.S. Bali (2006). Influence of crop residue, flyash and varying starter dosages on growth, yield and soil characteristics in rice (Oryza sativa L.) - wheat (Triticum aestivum L.) cropping system under irrigated conditions of Jammu region. Indian J. of Agric. Sci., 76 (1): 3-6.

Gomez, K.N. and A.A. Gomez (1984). Statistical procedures for agricultural research. John Wiley and Sons, New York, $2^{\text {nd }}$ ed., 68 P.

Goos, R.J. (1995). ATS: the multi - use sulfur fertilizer. The Official J. of the Fluid Fertilizer Foundation, P.O. Box 2097, Sioux City, IA 5110.

Jackson, M.L. (1967). Soil chemical analysis. Printic Hall of India, pp. 144197.

Mandal, K.G. ; A.K.Misra ; K.M. Hati ; K.K. Bandyopadhyay ; P.K. Ghosh and M. Mohanty (2004). Rice residue - management options and effects on soil properties and crop productivity. J. of Food, Agric. \& Environ., 2 (1): 224-231.

Martinez, M.T. ; C. Romers and J.M. Gaviler (1983). Interactions of foro-acids humics. A Findidad, X, 1 (1): 61-62.

Mishref, H.A. ; Kh.H. El-Hamdi and E.E. Khafagy (2000). Use of biofertilizers and organic manure to decrease the adverse environmental impacts of inorganic nitrogen in agro-ecosystems. J. Agric. Sci. Mansoura Univ., 25 (1): 555-560.

Muhammad, D. and R.A. Khattak (2009). Soil and nutrient concentrations of maize in Pressmud treated saline-sodic soils. Soil Environ., 28: 145155.

Pregle, F. (1945). Quantitative organic micro analysis $4^{\text {th }}$ Ed., J.X. Churchill Ltd. London.

Seehuber, C. ; L. Damerow A. Kunz and M. Blanke (2012). Effect of different types of thinning on source : sink relationship and fruit quality of plum. Erwerbsobstbau, 54 (1): 1-9.

Selim, E.M. ; A.S El-Neklawy and I.S. Shedeed (2009). Distribution and availability of soil phosphorus as affected by humic and phosphoric acid under drip irrigation system. Amer. Eurasian J. of Agric., and Enviro. Sci., 6 (2): 160-168.

Singh, J.P. (1988). A rapid method for determination of nitrate in soil and plant extracts. Plant and Soil, 110: 137-139.

Snedecor, G.W. and W.G. Cochran (1980). "Statistical Methods" 7th Ed. The lowa State Univ. Press, lowa, USA.

Suge, J.K. ; M. Omunyin and E.N. Omami (2011). Effect of organic and inorganic sources of fertilizers on growth, yield and fruit quality of eggplant (Solanum melongena L.). Archives of Applied Sci. Res., 3 (6): 470-479.

Walker, D.J. ; R. Clemente and M.P. Bernal (2004). Contrasting effects of manure and compost on soil $\mathrm{pH}$, heavy metal availability and growth of Chenopodium album $\mathrm{L}$. in a soil contaminated by pyriticmine waste, Chemosphere, 57: 215-224. 
Wilson, C.V. ; C. Anderson ; M.L. Rodriguez ; M.V. Arenas and P.J. Lopez (2011). Phytoextaction of gold and copper from nine tailing with Helianthus annus L. and Kalanchoe serrate L. Minerals Eng., 24 (13): 1488-1494.

Zadravec, P. (2011). Flower and fruitlet thinning in apple trees (part 1). SAD, Revija Sadjarstvo, Vinogradnistro in Vinarstvo, 22 (4): 3-5.

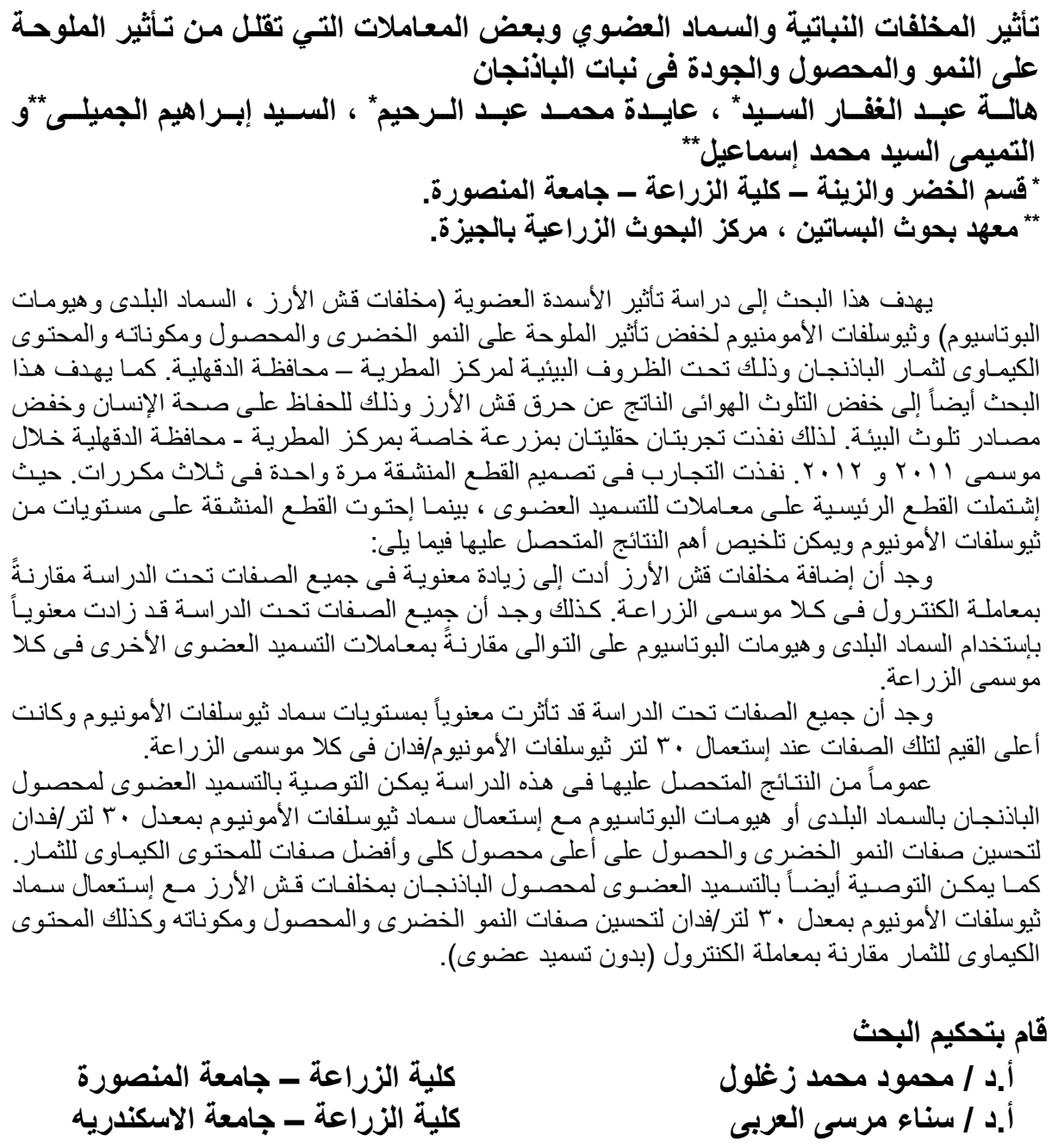

كلية الزراعة - جامعة المنصورة كلية الزراعة - جامعة الاسكندريه

$$
\text { قام بتحكيم البحث محثد }
$$

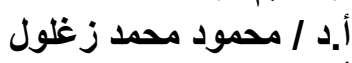

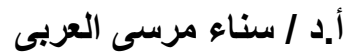


El-Sayed, Hala A. et al. 
Table 4: Plant height, number of leaves/plant, leaves area/plant, fresh and dry weight of leaves and total chlorophyll of eggplant after 65 days after transplanting as affected by organic fertilization and ammonium thiosulfate levels as well as their interaction during 2011 and 2012 seasons.

\begin{tabular}{|c|c|c|c|c|c|c|c|c|c|c|c|c|}
\hline \multirow{2}{*}{$\begin{array}{l}\text { Characters } \\
\text { Treatments }\end{array}$} & \multicolumn{2}{|c|}{ Plant height (cm) } & \multicolumn{2}{|c|}{$\begin{array}{l}\text { Number of } \\
\text { leaves/plant }\end{array}$} & \multicolumn{2}{|c|}{$\begin{array}{c}\text { Leaves area/plant } \\
\left(\mathrm{cm}^{2}\right)\end{array}$} & \multicolumn{2}{|c|}{$\begin{array}{l}\text { Fresh weight of } \\
\text { leaves (g) }\end{array}$} & \multicolumn{2}{|c|}{$\begin{array}{l}\text { Dry weight of } \\
\text { leaves }(\mathrm{g})\end{array}$} & \multicolumn{2}{|c|}{$\begin{array}{l}\text { Total Chlorophyll } \\
\text { (SPAD) }\end{array}$} \\
\hline & 2011 & 2012 & 2011 & 2012 & & 2012 & 2011 & 2012 & 2011 & 2012 & 2011 & 2012 \\
\hline \multicolumn{13}{|c|}{ A- Organic fertilization: } \\
\hline Without (control) & 64.76 & 64.47 & 31.57 & 32.14 & 79.20 & 79.58 & 84.23 & 85.84 & 13.19 & 14.32 & 73.86 & 73.89 \\
\hline RS $\quad(4 \mathrm{t} / \mathrm{fed})$ & 66.24 & 67.01 & 32.98 & 33.92 & 83.37 & 83.18 & 94.88 & 95.95 & 14.33 & 14.81 & 74.70 & 74.79 \\
\hline FYM $\left(15 \mathrm{~m}^{3} / \mathrm{fed}\right)$ & 75.35 & 77.01 & 39.60 & 40.09 & 94.91 & 96.00 & 134.24 & 137.06 & 19.90 & 20.33 & 75.40 & 75.52 \\
\hline $\mathrm{KH} \quad(2 \mathrm{~L} / \mathrm{fed})$ & 73.95 & 73.40 & 36.05 & 37.61 & 93.12 & 93.59 & 123.01 & 125.19 & 17.85 & 18.34 & 74.77 & 74.78 \\
\hline F. test & & & & & & & & & & & & \\
\hline LSD at $5 \%$ & 0.50 & 0.64 & 0.77 & 0.92 & 0.62 & 0.37 & 1.17 & 0.84 & 0.55 & 0.40 & 0.28 & 0.23 \\
\hline \multicolumn{13}{|c|}{ B- ATS levels: } \\
\hline $0 \mathrm{~L} / \mathrm{fed}$ (control) & 62.08 & 63.79 & 30.43 & 31.59 & 83.88 & 84.16 & 99.01 & 101.01 & 15.02 & 15.49 & 73.60 & 73.72 \\
\hline $10 \mathrm{~L} / \mathrm{fed}$ & 67.57 & 68.41 & 32.80 & 34.00 & 86.49 & 86.85 & 104.25 & 106.29 & 15.60 & 16.24 & 74.19 & 74.24 \\
\hline $20 \mathrm{~L} / \mathrm{fed}$ & 70.56 & 70.30 & 35.64 & 35.99 & 87.35 & 88.05 & 110.41 & 112.03 & 16.30 & 16.77 & 74.75 & 74.78 \\
\hline $30 \mathrm{~L} / \mathrm{fed}$ & 76.90 & 76.87 & 39.07 & 40.16 & 91.19 & 91.83 & 117.75 & 119.73 & 17.86 & 18.55 & 75.86 & 75.90 \\
\hline $40 \mathrm{~L} / \mathrm{fed}$ & 73.27 & 73.00 & 37.31 & 37.96 & 89.35 & 89.55 & 114.01 & 115.99 & 16.81 & 17.70 & 75.03 & 75.09 \\
\hline F. test & & & & & & & & & & & & \\
\hline LSD at $5 \%$ & 0.72 & 0.53 & 0.49 & 1.08 & 0.60 & 0.45 & 1.28 & 0.97 & 0.36 & 0.32 & 0.26 & 0.20 \\
\hline C-Interaction: $\mathrm{A} \times \mathrm{B}$ & & & & & & & & & & & NS & NS \\
\hline
\end{tabular}

FYM = farmyard manure

$\mathrm{KH}=$ Potassium humate

Table 5: Early yield weight (first 3 pickings), yield weight (from the fourth picking till end of harvesting), total yield of early yield and yield weight, fruit weight, diameter, height and firmness of eggplant as affected by organic fertilization and ammonium thiosulfate levels as well as their interaction during 2011 and 2012 seasons.

\begin{tabular}{|c|c|c|c|c|c|c|c|c|c|c|c|c|c|c|}
\hline \multirow{2}{*}{$\begin{array}{l}\text { Characters } \\
\text { Treatments }\end{array}$} & \multicolumn{2}{|c|}{$\begin{array}{c}\text { Early yield } \\
\text { weight }(t / f e d)\end{array}$} & \multicolumn{2}{|c|}{$\begin{array}{l}\text { Yield weight } \\
\text { (t/fed) }\end{array}$} & \multicolumn{2}{|c|}{ Total yield (t/fed) } & \multicolumn{2}{|c|}{$\begin{array}{l}\text { Fruit weight } \\
\text { (q) }\end{array}$} & \multicolumn{2}{|c|}{$\begin{array}{l}\text { Fruit diameter } \\
\text { (cm) }\end{array}$} & \multicolumn{2}{|c|}{$\begin{array}{l}\text { Fruit height } \\
(\mathrm{cm})\end{array}$} & \multicolumn{2}{|c|}{$\begin{array}{c}\text { Fruit firmness } \\
\left(\mathrm{Ib} / \mathrm{m}^{2}\right)\end{array}$} \\
\hline & & & & 2012 & 2011 & 2012 & 2011 & 2012 & & & & 2012 & & \\
\hline \multicolumn{15}{|c|}{ A- Organic fertilization: } \\
\hline Without (control) & 1.874 & 1.955 & 3.962 & 3.923 & 5.836 & 5.879 & 209.5 & 210.0 & 8.76 & 8.92 & 15.81 & 9.76 & 62.83 & 62.19 \\
\hline RS $\quad(4 \mathrm{t} / \mathrm{fed})$ & 2.311 & 2.253 & 4.652 & 4.789 & 6.963 & 7.042 & 253.0 & 256.7 & 9.70 & 9.86 & 10.63 & 10.88 & 60.59 & 59.26 \\
\hline FYM $\left(15 \mathrm{~m}^{3} / \mathrm{fed}\right)$ & 2.894 & 2.889 & 5.966 & 5.947 & 8.860 & 8.836 & 358.9 & 364.9 & 10.46 & 10.63 & 11.65 & 11.97 & 55.31 & 54.02 \\
\hline $\mathrm{KH} \quad(2 \mathrm{~L} / \mathrm{fed})$ & 2.542 & 4.132 & 5.381 & 5.330 & 7.923 & 9.461 & 303.1 & 311.1 & 10.00 & 10.18 & 11.20 & 11.48 & 56.84 & 55.31 \\
\hline F. test & & & & & & & & & & & & & & \\
\hline LSD at $5 \%$ & 0.115 & 0.124 & 0.137 & 0.101 & 0.136 & 0.213 & 3.9 & 2.6 & 0.10 & 0.04 & 0.23 & 0.06 & 0.12 & 0.03 \\
\hline \multicolumn{15}{|c|}{ ATS levels: } \\
\hline $0 \mathrm{~L} / \mathrm{fed}$ (control) & 2.182 & 2.150 & 4.576 & 4.580 & 6.758 & 6.729 & 231.0 & 235.7 & 8.82 & 9.03 & 9.98 & 10.24 & 61.22 & 60.05 \\
\hline $10 \mathrm{~L} / \mathrm{fed}$ & 2.283 & 2.294 & 4.605 & 4.808 & 6.888 & 7.102 & 253.3 & 257.4 & 9.27 & 9.47 & 10.35 & 10.60 & 60.22 & 58.73 \\
\hline $20 \mathrm{~L} / \mathrm{fed}$ & 2.397 & 2.367 & 5.078 & 5.029 & 7.475 & 7.396 & 286.5 & 285.9 & 9.84 & 10.00 & 10.81 & 11.03 & 59.13 & 57.48 \\
\hline fed & 2.610 & 2.592 & 5.427 & 5.330 & 8.038 & 7.922 & 329.0 & 336.9 & 10.55 & 10.67 & 11.62 & 11.84 & 57.00 & 56.05 \\
\hline $40 \mathrm{~L} / \mathrm{fed}$ & 2.555 & 4.633 & 5.264 & 5.240 & 7.819 & 9.873 & 305.8 & 312.5 & 10.17 & 10.30 & 18.85 & 11.40 & 56.90 & 56.16 \\
\hline F. test & & & & & & & & & & & & & & \\
\hline LSD at $5 \%$ & 0.124 & 0.142 & 0.124 & 0.110 & 0.123 & 0.241 & 4.7 & 2.2 & 0.14 & 0.05 & 0.38 & 0.05 & 0.18 & 0.04 \\
\hline C-Interaction: $\mathrm{A} \times \mathrm{B}$ & & & & & & & & & & & NS & & & \\
\hline
\end{tabular}

- Interaction: $\mathrm{A} \times \mathrm{B}$
$\mathrm{RS}=$ Rice residues 
Table 6: Nitrogen, phosphorus, potassium percentages, nitrate $\left(\mathrm{NO}_{3}\right)$ and nitrite $\left(\mathrm{NO}_{2}\right)$ contents in eggplant fruits at harvesting time as affected by organic fertilization and ammonium thiosulfate levels as well as their interaction during 2011 and 2012 seasons.

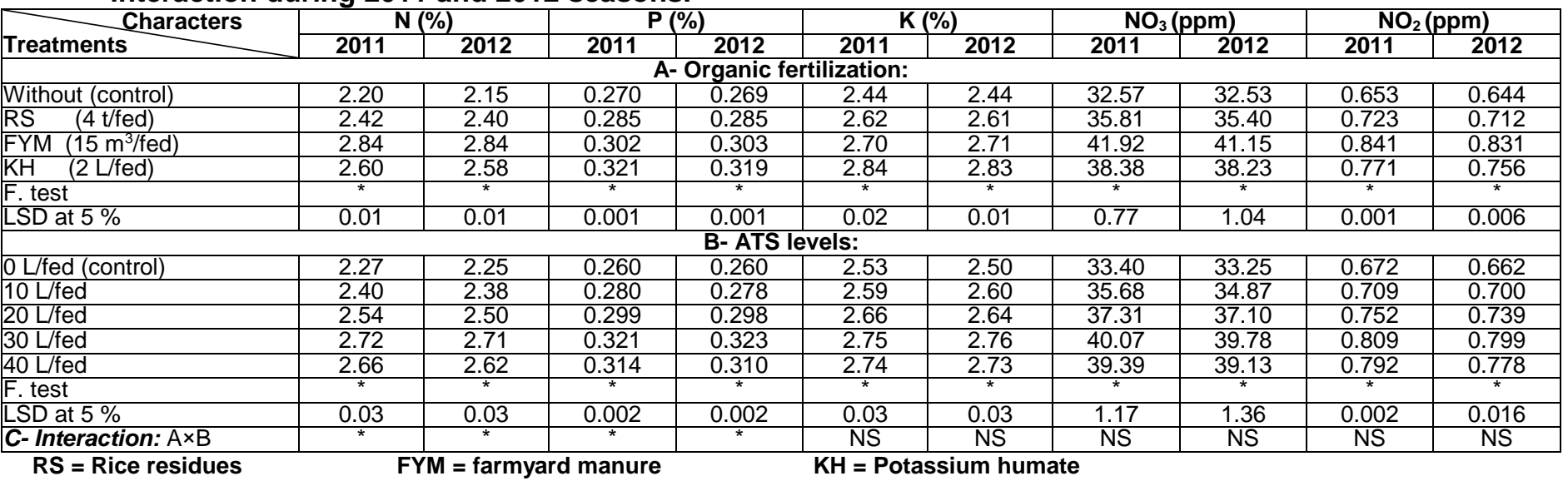

ATS = Ammonium thiosulfate $(12-0-0-26$ NPKS $)$

Table 7: Total soluble solids (TSS \%), ascorbic acid (Vitamin C), total iron (Fe) contents, dry matter and moisture percentages in eggplant fruits at harvesting time as affected by organic fertilization and ammonium thiosulfate levels as well as their interaction during 2011 and 2012 seasons.

\begin{tabular}{|c|c|c|c|c|c|c|c|c|c|c|}
\hline \multirow{2}{*}{$\begin{array}{l}\text { Characters } \\
\text { Treatments } \\
\end{array}$} & \multicolumn{2}{|c|}{ TSS (\%) } & \multicolumn{2}{|c|}{ Vitamin C $(\mathrm{mg} / 100 \mathrm{~g})$} & \multicolumn{2}{|c|}{$\mathrm{Fe}(p p m)$} & \multicolumn{2}{|c|}{$\begin{array}{c}\text { Dry matter } \\
(\%)\end{array}$} & \multicolumn{2}{|c|}{$\begin{array}{c}\begin{array}{c}\text { Moisture } \\
(\%)\end{array} \\
\end{array}$} \\
\hline & 2011 & 2012 & 2011 & 2012 & 2011 & 2012 & 2011 & 2012 & 2011 & 2012 \\
\hline \multicolumn{11}{|c|}{ A- Organic fertilization: } \\
\hline Without (control) & 4.38 & 4.36 & 8.30 & 8.30 & 27.48 & 27.33 & 4.74 & 4.76 & 95.25 & 95.23 \\
\hline RS $(4 \mathrm{t} / \mathrm{fed})$ & 4.66 & 4.65 & 9.76 & 9.77 & 31.19 & 30.66 & 4.97 & 4.98 & 95.03 & 95.01 \\
\hline FYM $\left(15 \mathrm{~m}^{3} / \mathrm{fed}\right)$ & 5.22 & 5.20 & 12.45 & 12.46 & 34.80 & 34.46 & 5.44 & 5.46 & 94.55 & 94.53 \\
\hline $\mathrm{KH} \quad(2 \mathrm{~L} / \mathrm{fed})$ & 4.94 & 4.93 & 11.25 & 11.29 & 37.40 & 37.01 & 5.14 & 5.17 & 94.85 & 94.82 \\
\hline F. test & & & & & & & & & & \\
\hline LSD at $5 \%$ & 0.02 & 0.01 & 0.03 & 0.05 & 0.44 & 0.33 & 0.01 & 0.01 & 0.01 & 0.01 \\
\hline \multicolumn{11}{|c|}{ B- ATS levels: } \\
\hline $0 \mathrm{~L} / \mathrm{fed}$ (control) & 4.58 & 4.55 & 9.70 & 9.73 & 29.33 & 29.19 & 4.86 & 4.87 & 95.13 & 95.12 \\
\hline $10 \mathrm{~L} / \mathrm{fed}$ & 4.68 & 4.67 & 9.99 & 9.95 & 31.03 & 30.62 & 4.96 & 4.98 & 95.03 & 95.01 \\
\hline $20 \mathrm{~L} / \mathrm{fed}$ & 4.81 & 4.80 & 10.35 & 10.39 & 32.73 & 32.41 & 5.09 & 5.10 & 94.90 & 94.89 \\
\hline $30 \mathrm{~L} / \mathrm{fed}$ & 4.99 & 4.97 & 11.19 & 11.18 & 35.57 & 35.76 & 5.27 & 5.29 & 94.72 & 94.70 \\
\hline $40 \mathrm{~L} / \mathrm{fed}$ & 4.94 & 4.93 & 10.98 & 11.02 & 34.93 & 33.84 & 5.19 & 5.21 & 94.80 & 94.78 \\
\hline F. test & & & & & & & & & & \\
\hline LSD at $5 \%$ & 0.01 & 0.04 & 0.18 & 0.12 & 1.48 & 1.38 & 0.03 & 0.04 & 0.03 & 0.04 \\
\hline C- Interaction: $\mathrm{A} \times \mathrm{B}$ & & & NS & NS & NS & NS & & & & \\
\hline
\end{tabular}

RS = Rice residues

FYM = farmyard manure 